\title{
KODE ETIK JURNALISME DI INDONESIA DAN INGGRIS RAYA
}

\author{
Astrid Puspita Sari \\ Dosen Program Studi Manajemen Produksi Pemberitaan \\ Sekolah Tinggi Multi Media (MMTC) Yogyakarta \\ Jalan Magelang Km. 6, Yogyakarta 55284 \\ No.HP.081225784378,E-mail: puspitasari.astrid7@gmail.com
}

\begin{abstract}
Abstrak
Etika bukan hanya soal kode etik atau aturan yang harus diikuti. Hal ini lebih terkait dengan prinsip-prinsip tentang yang benar dan yang salah dari perilaku manusia yang berlaku obyektif dan tidak memihak. Praktek jurnalisme sebagai suatu profesi menimbulkan permasalahan etika. Tulisan ini bermaksud membandingkan kode etik praktek jurnalistik yang dilakukan wartawan Inggris Raya dan Indonesia serta membahas beberapa contoh malpraktek etika kerja jurnalistik. Walaupun di kedua negara tersebut menjunjung kebebasan pers dan kebebasan informasi. Di Inggris sendiri media lebih dibatasi oleh hukum dan kode etik tertentu secara spesifik. Sedangkan di Indonesia, media tetap dibatasi oleh hukum tapi tidak secara spesifik meskipun kode etik jurnalistik juga digunakan sebagai salah satu aturan yang ada. Tulisan ini menyajikan perbedaan dalam hal etika jurnalistik yang digunakan oleh wartawan dari kedua negara tersebut.
\end{abstract}

\begin{abstract}
Journalism Code of Ethics in Indonesia and United Kingdom. Ethics is not just a matter of codes of conducts or rules to be followed. It is more related to principles concerning the rights and wrongs of human conduct applied objectively and impartially. The practice of journalism as a profession raises many ethical issues. This essay compares the journalist's practice code of ethics between United Kingdom and Indonesia and also discusses some examples of malpractices ethics of journalistic work. In Britain, the media are more restricted by specific law and codes of conducts. Whereas, in Indonesia, the media are restricted by law but not in specific areas even though also using the journalistic codes of conducts as one of the rules. However, both countries they have the idea of free press and freedom of information. This essay presents those differences in terms of ethics that is being used by the journalist from both countries.
\end{abstract}

Keywords: code of ethics, United Kingdom, Indonesia, journalists

\section{PENDAHULUAN}

Etika dan dunia jurnalistik adalah dua hal yang tidak bisa dipisahkan. Dewasa ini, jurnalis diharapkan dapat memenuhi standar dan prinsip-prinsip dalam dunia profesional yang sering disebut sebagai Kode Etik. Society Professional Journalist menjelaskan pengertian seorang profesional, yakni jurnalis memiliki peranan dan tugas penting dengan selalu mencari kebenaran dan memberikan fakta atas isu-isu secara komprehensif dan berimbang.

Kadangkala, sangatlah sulit bagi jurnalis untuk mendefinisikan mana yang benar dan salah. Untuk memutuskan suatu hal benar ataupun salah juga tidak lepas dari hasil konstruksi pemikiran tiap individu jurnalis 
tersebut yang bisa saja menjadi sangat subjektif. Melalui Kode Etik wartawan, jurnalis dapat mendefinisikan panduan profesional tentang mana yang baik dan buruk secara manusiawi seperti yang didefinisikan oleh Conrad (1988).

Sebelum membahas etika jurnalisme ada baiknya mengetahui pengertian etika. Etika adalah sistem dari prinsip, moralitas, atau kode etik. Etika adalah nilai dan aturan hidup yang dikenali oleh individu, grup, atau budaya yang mencari panduan dalam berkehidupan dan mana yang baik ataupun buruk, mana yang benar dan mana yang salah (Conrad, 1988:5). Frost (2007:9) menegaskan jika etika adalah suatu cara untuk mempelajari moralitas yang mengizinkan keputusan dibuat individu ketika menghadapi kasus spesifik dari dilema moral.

Konsep utama etika kebanyakan beradu pada area kebebasan, demokrasi, kebenaran, objektivitas, kejujuran, dan privasi. Senada dengan hal tersebut, menurut Conrad (1988:37) ada empat area utama etika seorang jurnalis yang perlu diperhatikan antara lain objektivitas dalam melaporkan dan menulis, konflik kepentingan, privasi, dan selera yang baik. Area tersebut sebenarnya sangat fundamental untuk diliput secara baik karena faktanya banyak jurnalis saat ini dipertanyakan terkait etika dan kredibilitasnya. Pekerjaan jurnalistik adalah pekerjaan terhormat, namun bukanlah suatu rahasia umum apabila banyak pula yang tidak menghormati esensi profesionalismenya. Integritas profesional adalah batu penjuru dari kredibilitas jurnalis, tetapi kadangkala mereka tidak bisa memutuskan dengan tepat bagaimana mereka membangun panduan etika untuk dunia pemberitaan di tempat kerjanya.

Profesi jurnalisme memiliki tujuan terhormat, mereka perlu memerhatikan sirkulasi informasi, termasuk berita, komentar, dan pendapat. Oleh karena itu, wartawan memerlukan kode etik untuk mencegah mereka dari malpraktik jurnalistik dalam tindakan mereka. Anggota masyarakat berbagi tanggung jawab untuk berperilaku etis dan mengadopsi kode etik untuk menyatakan prinsip-prinsip dan standar dalam masyarakat. Oleh karena itu, kode praktis etik kemudian dibuat oleh beberapa regulator, komite/aliansi wartawan, atau bahkan pemerintah. Etika mengharuskan setiap wartawan untuk menentukan bagaimana membangun hubungan saling percaya dengan penonton yang bergantung pada keakuratan, profesionalisme, dan keberimbangan media berita mereka (Conrad, 1988:17).

Di Inggris, media lebih dibatasi oleh hukum dan kode etik secara spesifik. Contohnya adalah adanya undang-undang yang secara spesifik mengatur apabila gambar ataupun video anak-anak tanpa seizin orang tua mereka tidak dapat ditampilkan di televisi. Sementara itu, di Indonesia media juga dibatasi oleh hukum dan juga kode etik jurnalistik tertentu, tetapi tidak secara spesifik seperti halnya di Inggris. Contohnya adalah wartawan Indonesia tidak menyebutkan dan menyiarkan identitas korban kejahatan susila dan tidak menyebutkan identitas anak yang menjadi pelaku kejahatan. Walaupun di kedua negara mengusung konsep kebebasan pers dan kebebasan informasi, tulisan ini akan menyajikan perbedaan dalam hal etika yang digunakan oleh wartawan dari kedua negara termasuk beberapa contoh penyimpangan etika dalam dunia jurnalistik.

\section{ETIKA JURNALISTIK WARTAWAN}

Etika bukanlah sebatas urusan kode etik atau aturan yang harus diikuti. Hal ini lebih terkait dengan prinsip yang benar dan yang salah dari perilaku manusia yang 
berlaku secara objektif dan tidak (Belsey and Chadwick, 1992:10). Sudah bukan rahasia umum lagi apabila profesi jurnalisme menimbulkan banyak permasalahan etika. Masih segar dalam ingatan kasus-kasus media online hingga wartawan amplop. Salah satunya misalnya kasus lima jurnalis yang dipanggil Dewan Pers pada tahun 2010 karena diduga meminta jatah dalam proses penjualan saham perdana PT Krakatau Steel. Kasus ini hanya sebagian kecil dari permasalahan etika lainnya. Persaingan yang ketat antarmedia dan adanya kewajiban wartawan dalam menyediakan cerita yang menarik serta diperparah dengan adanya tenggat waktu yang ketat terkadang membuat para wartawan mengabaikan etika jurnalistik yang ada (https://m.tempo.co/ $\mathrm{read} / \mathrm{news} / 2010 / 12 / 01 / 173296013 /$ inilahkeputusan-dewan-pers-soal-skandal-sahamkrakatau-steel-itu diakses pada 9 September 2015, pukul 12.17 WIB).

Publik saat ini juga cukup cerdas untuk membedakan mana yang benar atau salah. Konstruksi pemikiran mereka pun sudah lebih luas yang dipengaruhi oleh banyak hal dan juga era kebebasan informasi yang saat ini berlangsung. Hal ini mungkin dapat berlangsung dengan baik untuk waktu yang singkat, tetapi tidak dapat berlangsung lama. Frost (2007:11) mendefinisikan seorang wartawan yang baik sebagai seseorang yang melakukan pekerjaan secara akurat untuk khalayak luas. Dia menekankan untuk menggunakan cara yang dibenarkan secara moral, aktual, jujur, dan faktual berdasarkan kepentingan informasi.

Objektivitas yang benar sejatinya mustahil untuk dicapai karena setiap individu masing-masing dibentuk oleh latar belakang dan pengalaman yang berbeda. Hal ini mau tidak mau dipengaruhi bagaimana seseorang melihat hal- hal dan bertindak sebagai wartawan. Bahkan, sebagian besar wartawan sekarang berbeda dengan masa lalu. Mereka berpendidikan baik dan mendapatkan informasi cukup tentang bagaimana menjadi seorang jurnalis yang baik. Akan tetapi, pendidikan yang tinggi sebagai bekal sebelum menjadi wartawan juga dirasa kurang. Leveson (2013:223) menekankan bahwa industri umumnya dan pengusaha khususnya harus menempatkan prioritas tinggi dalam pelatihan jurnalistik. Hal ini penting untuk memastikan semua wartawan memahami konteks hukum dan etika.

Akan tetapi, wartawan harus ingat bahwa objektivitas dan kebenaran adalah tujuan utama mereka untuk memenangkan kepercayaan penonton. Hal ini dapat dicapai dengan membangun kode etik pribadi. Conrad (1988:37) mengakui bahwa etika adalah bagian dari memberikan informasi bagi pembaca atau pemirsa secara adil, peliputan berita yang seimbang.

Sebagai seorang wartawan beretika, mereka harus mengatasi kecenderungan yang manusiawi terhadap perasaan pribadi. Seorang wartawan yang baik harus bisa dipercaya keduanya, kredibel dan akurat dalam menyampaikan informasi. Hal ini merupakan satu metode untuk meningkatkan kepercayaan penonton. Jika penonton selalu disajikan peliputan berita yang adil, akurat, dan sesuai dengan kebenaran, lambat laun mereka akan percaya dengan wartawan tersebut.

Survei yang diadakan regulator media di Inggris, Ofcom menyatakan bahwa radio adalah sumber berita paling terpercaya yang mengalahkan baik televisi maupun internet. Jumlah responden yang memilih radio sebagai sumber terpercaya mencapai 66 persen responden dari polling tersebut. Sementara 
itu, penilaian angka kredibilitas televisi di Inggris hanya mencapai $54 \%$ dari responden. Survei ini menunjukkan jika situs berita online telah mengalahkan berita televisi sebagai sumber paling terpercaya yang mencapai $58 \%$. Sementara itu, dari keseluruhan responden yang diwawancara hanya $34 \%$ yang percaya dengan koran/surat kabar Inggris. Riset tersebut berhasil mewawancarai sekitar 1.824 orang dewasa sebagai responden pada tahun 2010. Hal ini berarti bahwa masyarakat di Inggris belum cukup puas dengan media Inggris karena jumlah ini tidak cukup untuk memenangkan kepercayaan dari penonton (http://media. ofcom.org.uk/ diakses pada 2 Maret 2014 pukul 12.03 WIB).

Dalam amandemen pertama, kebebasan informasi direformasi dan pers diberikan hak untuk bebas mencetak berita dan hak rakyat untuk mengetahui pers bertugas untuk mencetak atas nama rakyat (Conrad, 1988:11). Walaupun itu bukanlah jaminan pers bebas, tetapi untuk media menjadi tempat mereka dapat mengungkapkan realitas pers yang benar-benar bebas. Era saat ini, wartawan menghadapi banyak permasalahan etika dalam pekerjaan mereka tidak hanya di depan publik, tetapi juga pada banyak jenis organisasi saat melakukan pekerjaan mereka. Sebagai seorang individu, Cutlip dalam Conrad (1988:241) menyatakan permasalahan etika yang fundamental adalah "how to maintain credibility. how to represent the client, yet stay separate and independent to tell the truth". Sementara itu, bagi masyarakat jelas mengetahui bagaimana wartawan meliput isu-isu dan berlaku jujur atas nama masyarakat.

Sementara itu, survei AC Nielsen di 10 kota besar di Indonesia tentang keseluruhan konsumsi media di kota-kota baik di Jawa maupun Luar Jawa menunjukkan bahwa televisi masih menjadi medium utama yang dikonsumsi masyarakat Indonesia (95\%), disusuloleh internet $(33 \%)$, radio $(20 \%)$, surat kabar $(12 \%)$, tabloid $(6 \%)$, dan majalah (5\%). Akan tetapi, ketika dilihat lebih lanjut, ternyata terdapat perbedaan yang menarik antara pola konsumsi media di kota-kota di Jawa bila dibandingkan dengan kota-kota di luar Jawa. Angka konsumsi media televisi lebih tinggi di luar Jawa (97\%), disusul oleh radio $(37 \%)$, internet $(32 \%)$, koran $(26 \%)$, bioskop (11\%), tabloid (9\%), dan majalah (5\%). Nielsen Audience Measurement melaksanakan Pengukuran Kepemirsaan TV untuk 10 kota besar di Indonesia (Jakarta, Surabaya, Medan, Semarang, Bandung, Makassar, Yogyakarta, Palembang, Denpasar, dan Banjarmasin) dengan populasi televisi sebanyak 49.525.104 individu berusia 5 tahun ke atas (http://www.nielsen. com/id/en/press-room/2014/nielsen-konsumsimedia-lebih-tinggi-di-luar-jawa.html diakses pada 11 Februari 2016, pukul 09.05 WIB).

Data tersebut sedikit banyak menunjukkan jika masyarakat Indonesia masih mengandalkan media dalam mendapatkan informasi. Jumlah yang cukup signifikan ini seharusnya membuat wartawan Indonesia memiliki tanggung jawab besar dalam menyampaikan informasi dan meliput berita yang sesuai dengan etika yang ada.

Selain itu, berbicara tentang kepentingan publik, publik berhak mengetahui kebenaran yang menarik bagi mereka. Seorang wartawan harus memenuhi pekerjaan mereka dengan mengungkap cerita dan melaporkan kembali dengan fakta-fakta dan bukti-bukti bagi masyarakat untuk mengetahui dan melihat. Akan tetapi, bahkan untuk wartawan, ada batas tertentu yang mereka tidak bisa melewatinya terutama untuk jurnalis investigasi karena dapat mengakibatkan pelanggaran hukum. 
Di Inggris, Kode Etik Jurnalistik dibuat oleh Serikat Perkumpulan Jurnalis (The National Union of Journalist), Asosiasi Penerbit (The Newspaper Publishers Association), dan Dewan Standar Penyiaran (The Broadcasting Standards Council). Suatu kontrol standar etika biasanya ditegakkan baik oleh hukum maupun badan pengawas hukum. Selain itu, ada Ofcom yang juga merupakan regulator independen dan otoritas untuk persaingan dalam industri komunikasi Inggris, yang bertanggung jawab di televisi, radio, telekomunikasi, dan layanan komunikasi nirkabel. Ada juga Press Complaints Commissions (PCC) atau komisi untuk komplain dari penonton di Inggris.

Sementara itu di Indonesia, Kode Etik telah dibuat oleh organisasi wartawan bernama Persatuan Wartawan Indonesia untuk semua wartawan Indonesia baik untuk dicetak, disiarkan dan untuk wartawan online. Untuk area penyiaran, ada Komisi Penyiaran Indonesia yang merupakan badan pengawas independen di bawah pemerintah yang bertanggung jawab mengawasi semua program yang disiarkan.

Sebelum era reformasi, media di Indonesia dikendalikan oleh pemerintah. Bahkan populer pula istilah untuk media saat itu sebagai corong pemerintah karena isi beritanya yang kebanyakan tentang pemerintah pada saat itu. Semua informasi yang beredar di masyarakat diawasi dengan tujuan mengubah atau menghilangkan bagian-bagian tertentu yang dianggap tidak dapat diterima atau menyinggung. Hal ini termasuk dari pengawasan program buku, majalah, pertunjukan, film, televisi dan radio, laporan berita, dan media komunikasi lainnya. Setelah adanya Undang-Undang Nomor 40 tahun 1999, media memiliki peranan baru dan lebih bebas dalam menyampaikan informasi dari sebelumnya.

\section{INDONESIA DAN INGGRIS RAYA}

Pers adalah lembaga yang tidak boleh dicampuri oleh pihak mana pun. Sayangnya, tidak banyak yang mengetahui bahwa pers yang sebenarnya juga memiliki keterbatasan tertentu dalam melaksanakan tugasnya. Dalam hal etika yang terkait dengan isu-isu moralitas, apa yang benar atau salah, wartawan tidak bisa hanya bergantung kepada diri mereka sendiri. Oleh karena itulah, muncul badan pengawas dan kode etik jurnalistik seperti sekarang ini untuk mencegah tindakan jurnalistik yang tidak diinginkan.

Di Inggris, media sudah dibatasi hukum, baik pidana maupun perdata, daripada di kebanyakan negara-negara lain yang demokratis seperti rahasia resmi, kecabulan, hujatan, hasutan (Belsey dan Chadwick, 1992:6). Sejak tahun 1936, The National Union of Journalist (NUJ) telah menetapkan kode etik wartawan Inggris dan Irlandia sebagai prinsip utama untuk dilakukan. NUJ menyebutkan bahwa wartawan berusaha memastikan bahwa informasi yang disebarkan adalah jujur pada saat disampaikan, akurat dan adil.

Namun, pada kasus yang terjadi antara Jonathan Aitken dan koran The Guardian di Inggris pada tahun 1999 tidak menunjukan jika wartawan berusaha jujur dalam mendapatkan informasi. (http://news.bbc. co.uk/2/hi/uk_news/363478.stm diakses pada 9 September 2015, pukul 11.00 WIB). Awalnya, The Guardian bermaksud menunjukkan Jonathan Aitken, seorang anggota parlemen konservatif yang korup dengan mencoba untuk membuktikan bahwa dia tinggal di Ritz Hotel di Paris. Peter Preston, wartawan yang mengirim faks ke hotel di House of Commons berpurapura menjadi Aitken bertanya tentang tagihan. Dalam hal ini, tidak hanya informasi yang tidak 
akurat dan adil, akan tetapi dalam kasus itu wartawan juga tidak mendapatkan bahan berita dengan cara yang jujur.

Padahal dalam Kode Etik NUJ, seorang wartawan harus jujur dan langsung dalam melibatkan bukti yang tidak dapat diperoleh dengan cara yang jujur. Hal ini seharusnya tidak terjadi jika wartawan tidak mencoba untuk meliput cerita secara tidak benar dan tidak profesional. Kemudian, seorang wartawan memiliki kewajiban untuk melakukan yang terbaik untuk memperbaiki ketidakakuratan seperti yang tertulis dalam Kode Etik NUJ (http://www.nuj.org.uk/about/nuj-code/ diakses pada 19 Februari 2014, pukul 15.02 WIB).

Selanjutnya, dalam Kode Etik NUJ juga menyatakan bahwa wartawan tidak boleh melakukan apa pun untuk mengganggu kehidupan pribadi siapa pun, kesedihan atau kesusahan kecuali dibenarkan oleh pertimbangan kepentingan umum. Wartawan mungkin terlibat dalam kegiatan kriminal, penipuan, dan pelanggaran untuk mendapatkan berita. Bahkan, ada kasus pelanggaran yang dilakukan oleh beberapa wartawan pada 10 Februari 2003. Catherine Zeta Jones menggugat ke pengadilan tinggi di pusat kota London dengan membuat $£ 500.000$ klaim kerusakan terhadap majalah Hello!. Kasus ini terjadi ketika Zeta Jones berada di pernikahannya dengan Michael Douglas, beberapa fotografer secara ilegal mengambil gambar dari dalam pernikahan mereka. Setelah itu, mereka menjual foto-foto ini ke majalah Hello! (http://www. telegraph.co.uk/news/uknews/1490310/Hellomagazine-wins-Zeta-Jones-wedding-appeal. html diakses pada 9 September 2015, pukul 12.24 WIB).

Di sisi lain, data dari The Times / Mirror Daily menunjukkan bahwa media
Inggris memiliki pengaruh yang baik pada masyarakat, yang mencapai 66 persen untuk televisi dan diikuti oleh surat kabar, yaitu sekitar 38 persen (http://www.bbc.co.uk/blogs/ haveyoursay/2010/05/which_medium_do_ you_most_trust.html diakses pada 11 Februari 2016, pukul 11.34 WIB).

Sementara, survei yang diambil dari BBC, Reuters dan Media Centre menunjukkan peningkatan tingkat kepercayaan di publik Inggris terhadap media Inggris. Bila dibandingkan dengan banyak negara lain hal ini masih terbilang rendah. Namun, Inggris masih menjadi satu-satunya negara di mana banyak orang cenderung mempercayai pemerintah dibandingkan media berita. Fakta ini merupakan pengingat bagi semua wartawan dan semua orang yang berada di dunia berita untuk menjamin kualitas informasi yang mereka berikan kredibel dan dapat diandalkan.

Di Indonesia, Kode Etik Jurnalistik dibuat untuk pers sehingga mereka tidak melanggar batas-batas dalam menyampaikan informasi. Jika ada yang melenceng, Dewan Pers akan melakukan dengar pendapat dan pensensoran. Ada kode etik yang dibuat oleh Aliansi Jurnalis Independen (AJI) dan kode etik jurnalistik Persatuan Wartawan Indonesia (PWI) (http://www.mediawise.org. uk/indonesia/ diakses pada 9 September 2015, pukul 11.50 WIB).

Pada dasarnya, prinsip-prinsip utama dari kode etik menyatakan bahwa tidak berisi informasi palsu, fitnah, sadis dan cabul, konten yang mengandung prasangka dan kebencian terkait dengan suku, agama, ras serta tindakan kekerasan; tidak melakukan diskriminasi atas dasar konten yang mengandung seks dan bahasa perbedaan, dan tidak merendahkan orang yang lemah, miskin, sakit, cacat mental, atau cacat 
fisik. Wartawan juga memiliki kewajiban untuk mengungkapkan koreksi, hak jawab, atau ralat.

Contoh kasus dalam berita online adalah kasus Imanda Amalia yang dikabarkan sebagai warga negara Indonesia yang tewas saat kerusuhan di Mesir pada Februari 2011. Kabar ini datang dari sebuah posting di akun facebook. Dia dikabarkan berada di Mesir sebagai relawan PBB Badan Bantuan dan Pekerjaan (UNRWA). Meskipun tidak ada data yang jelas dari KBRI dan Kementerian Luar Negeri, namun beberapa media online seperti detik.com dan Tribunnews telah melaporkan dalam berita mereka, bahkan diikuti oleh beberapa stasiun televisi swasta sehingga sebagian besar orang percaya. Kemudian, ternyata hal itu hanya isu belaka dan Kementerian Luar Negeri Indonesia akhirnya memastikan bahwa tidak ada warga yang meninggal di Mesir. Kasus ini jelas melanggar kode etik karena mengandung informasi palsu dan diterbitkan tanpa bukti.

Selain itu, wartawan Indonesia diharapkan mengejar jalur etis dalam memperoleh dan mempublikasikan informasi serta dalam mengidentifikasi sumber informasi. Kasus pelanggaran kode etis lain terjadi sekitar tahun 2010. Seorang presenter berita Indonesia, Indy Rahmawati dari TV One tersandung dalam kasus makelar kasus. Indy melakukan berita palsu dengan menunjukkan sumber yang disuap dengan uang untuk muncul dalam programnya. Meskipun pembelaan Indy bahwa sumber sering tampil sebagai narasumber di media lain, hal ini tidak dapat dianggap normal karena Indy melanggar etika jurnalistik nomor 2 yang menyatakan wartawan Indonesia mengambil cara profesional untuk melaksanakan tugas jurnalistik. Indy diskors dari pekerjaannya dan program televisi yang ia bawakan serta diberi peringatan keras oleh dewan pers. Hal ini sesuai dengan Pasal 1 Wartawan Indonesia bersikap independen, menghasilkan berita yang akurat, berimbang, dan tidak beritikad buruk. Sementara itu, di dalam Pasal 2 disebutkan jika wartawan Indonesia menempuh cara-cara yang profesional dalam melaksanakan tugas jurnalistik (http://dewanpers.or.id/peraturan/ detail/190/kode-etik-jurnalistik diakses pada 9 September 2015, pukul 11.59 WIB).

\section{SIMPULAN}

\begin{tabular}{lrr}
\multicolumn{1}{c}{ Pers bebas tidaklah mudah untuk } \\
dilakukan, bahkan dapat & menimbulkan \\
pelanggaran & etika dan & penyampaian
\end{tabular} informasi yang kebablasan. Sejatinya pers bebas dilakukan, yakni untuk memenuhi hak dasar manusia untuk berkomunikasi dan memperoleh informasi. Akan tetapi, dalam praktik jurnalisme, semua wartawan harus menyadari keberadaan tanggung jawab sosial dan kemajemukan sosial. Pelanggaran etika jurnalistik tidak boleh dibiarkan karena akan memengaruhi citra media umumnya dan mengecewakan kepercayaan masyarakat. Jadi, untuk memastikan pelestarian kebebasan pers dan memenuhi hak-hak publik, moral/ profesional, kode etik diperlukan yang dapat berfungsi sebagai pedoman operasional dalam pelestarian integritas dan profesionalisme wartawan.

Oleh karena itu, Ofcom untuk media Inggris dan Dewan Pers Indonesia sebagai badan independen yang berfungsi untuk mengawasi pelaksanaan kode etik diharapkan dapat menuntut kasus pelanggaran kode etik jurnalistik. Hal ini harus sesuai dengan prosedur yang berlaku dan memberikan rekomendasi kepada pers perusahaan bersangkutan untuk melakukan koreksi atau ralat. Kontrol terhadap ketaatan kode ini dan penerapan sanksi dari 
komunitas pers untuk setiap pelanggaran kode ini benar-benar dilaksanakan oleh organisasi seperti itu harus dibentuk untuk tujuan itu.

Akhirnya, seorang wartawan haruslah menyadari jika mereka memiliki kuasa untuk membuat pilihan tentang apa yang harus dimasukkan ke dalam beritanya atau tidak memasukannya termasuk bagaimana mendapatkan sumber untuk mendukung berita mereka. Frost (2007:43) menegaskan bila seorang wartawan perlu menentukan sejak awal alasan mengapa ia menutupi suatu berita secara moral ataupun memutuskan untuk mengungkapnya. Hal ini bertujuan tidak hanya untuk menarik penonton untuk membaca, menonton, atau mendengarkan berita tersebut, namun juga untuk menjalankan etika dalam menjalankan profesi sebagai wartawan.

\section{KEPUSTAKAAN}

Besley, A. \& R. Chadwick. 1992. Ethical Issues in Journalism and the Media. London: Routledge.

Conrad, C. Fink. 1988. Media Ethics in the Newsroom and Beyond. Georgia: McGraw-Hill book Company.

Dewan Pers (Indonesia Press Council), (n.d). Available at: www.dewanpers.or.id [diakses 25 February 2014].

Frost, C. 2007. Journalism Ethics and Regulation. 2nd Edition. Harlow: Pearson Education Limited.

Mair, John. 2013. After Leveson? The Future for British Journalism. Suffolk: Arima Publishing.

Francess, Quinn. 2013. Law for Journalists. Harlow: Pearson Education Limited.

\section{Pustaka Laman}

http://dewanpers.or.id/peraturan/detail/190/ kode-etik-jurnalistik diakses pada 9 September 2015, pukul 11.59 WIB

( h t t p s : // m . t e m p o . c o/ r e a d / news/2010/12/01/173296013/inilahkeputusan-dewan-pers-soal-skandalsaham-krakatau-steel-itu diakses pada 9
September 2015, pukul 12.17 WIB)

http://nasional.kompas.com/read/2012... ik.Jurnalistik diakses pada 22 Februari 2014, pukul 13.00 WIB

http://news.bbc.co.uk/2/hi/uk_news/363478. stm diakses pada 9 September 2015, pukul 11.00 WIB

https://www.spj.org/pdf/spj-code-of-ethics. pdf diakses pada 9 September 2015, pukul 11.08 WIB.

http://www.nuj.org.uk/about/nuj-code/ diakses pada 19 Februari 2014, pukul 15.02 WIB.

http://www.mediawise.org.uk/codes-ofconduct/codes/ diakses pada 18 Februari 2014, pukul 13.29 WIB.

http://www.mediawise.org.uk/indonesia/ diakses pada 9 September 2015, pukul 11.50 WIB.

http://www.nielsen.com/id/en/pressroom/2014/nielsen-konsumsi-medialebih-tinggi-di-luar-jawa.html diakses pada 11 Februari 2016, pukul 09.05 WIB.

h t t p :// w w w. b b c.co.uk/b1og s / haveyoursay/2010/05/which_medium do_you_most_trust.html diakses pada 11 Februari 2016, pukul 11.34 WIB.

http://www.telegraph.co.uk/news / uknews/1490310/Hello-magazinewins-Zeta-Jones-wedding-appeal.html diakses pada 9 September 2015, pukul 12.24 WIB.

Ofcom, (2012) Code of Conduct. Available at : http://media.ofcom.org.uk/ diakses pada 2 Maret 2014 pukul 12.03 WIB. 